$\mathbb{T}$ periodica polytechnica

\author{
Social and Management Sciences \\ $17 / 1(2009) \quad 31,40$ \\ doi: 10.3311/pp.so.2009-1.03 \\ web: http://www.pp.bme.hu/so \\ (c) Periodica Polytechnica 2009
}

RESEARCH ARTICLE

\section{The impact of GATS on public services and local governments}

Lilla Veronika Kiss

Received 2010-01-05

\begin{abstract}
Globalisation has put considerable strain on trade in public services. This paper deals with the tremendous impact of the General Agreement on Trade in Services (GATS), which involves the liberalisation and privatisation of public services. The overall goal is to explore the main challenges to success factors of local government implementation of the privatisation of public services. The main hypothesis is that market orientation in public management will lead to greater efficiency for governments, without having negative side effects on other local objectives and considerations. With regard to these effects the paper concentrates on the sustainable management of public services.
\end{abstract}

This paper is structured in five main sections, as follows: After some introductory thoughts about public services and governance, Section 2 examines the multifaceted process of the privatisation of public services. Based on an examination of WTO documents and discussions, Section 3 outlines a theoretical framework for measuring the aggregate attribute of the GATS and examines its effects on governance. In Section 4 the author proposes success factors for achieving competitive local governance and suggests local strategy objectives with a view to strengthening strategic planning, adequate funding, transparency and public participation. The concluding remarks in Section 5 highlight the main public management considerations for local governments.

\section{Keywords}

public services · governance · privatisation - General Agreement on Trade in Services (GATS) · local governments · public management

\section{Lilla Veronika Kiss}

Department of Economic Policy, BME, 1111 Budapest, Múegyetem rkp. 9., Hungary

e-mail: kisslillav@freemail.hu

\section{Introduction}

The core duty of national and local governance worldwide is to ensure that all citizens have access to affordable and adequate basic public services. Public services involve the provision of services by public entities, such as education, health services, infrastructural services (basic telecommunication, energy and local transportation services), military and police. Many public services are supplied by either the local government/agency or a government owned company.

The power of governments to determine and deliver public services is - due to the rules of the global economy and the negative externalities of the global economy and financial crisis gradually being eroded. The most advantageous way to finance and manage public services efficiently is often the privatisation of government-owned companies. Privatisation is a major trend in emerging countries, as well as in transition economies. As regards stabilisation, World Bank analyses [19] argue that one of the main determinants of privatisation is the desire to tackle problems of financial imbalances 1 Privatisation has been indicated by Veress [13] as a key way to a more market-oriented policy, to reduce public intervention and to favour fiscal and financial stabilisation. Privatisation may actually have effects on the stabilisation and development of financial markets and could influence the labour market but may also cause market failures and societal as well as environmental problems.

Due to the pressure coming from the European Union and international organisations - for greater and deeper financial integration, as well as trade induced competition - structural changes have been put into place to limit aggregate government spending.

Each change has posed challenges to local governments and the fabric of communities. Analysing the merit of this claim and of analogous local policy recommendations is one of the key points of the paper.

The paper intends to:

\footnotetext{
${ }^{1}$ From 1977 to 1997,1865 transactions are reported by the World Bank in more than 100 countries, with approximately US\$ 750 bn of revenues. During this period state-owned enterprise value added as a percentage of GDP in privatising countries decreased on average from $9 \%$ to $6 \%$.
} 
- examine and discuss the main factors and impact of privatisation in the public sector, based on experience in the European Union;

- discuss the substantive scope of the General Agreement on Trade in Services;

- provide practical guidance, by identifying the main leadership challenges and success factors that will assist local governments in the implementation of privatisation, in order to make performance assessments run more smoothly and contribute to improved organisational performance.

The hypothesis of the study is that local economic policy and certain areas of public management policy have particular importance for local government efficiency and performance.

\subsection{Public services}

Apart from the differences that exist between countries because of historic development, varying political and social values, the main public services are often classed as universal service obligations, which involve the provision of services by public entities, such as education, health services, infrastructural services (basic telecommunication, energy and local transportation services), military and police services. In Europe, for example, there is a strong tradition of public health, while health services in the United States are predominantly supplied by private institutions differing notions of the appropriate role of the state and the market [18]. The supply of public services also depends on the resources available to governments, which vary in developed and developing countries.

The term public services can be used in a rather general way to refer to services considered as a public or common good. This understanding of public services is thus based on a sectoral approach and focuses on what is supplied. In the European context this understanding is related to the notion of a universal service obligation, focusing on to whom and under which conditions the service is supplied. The concept of public services can be based on the understanding that a service is provided by a public entity, either by the government itself, by a governmental agency or by an enterprise. The enterprise may be privately owned, but the demand it meets and the financing come from public agencies. This concept focuses therefore on who is supplying the service.

\subsection{Governance of public services}

Governance shapes public policy and provides public goods and services at national, regional and local level. The main concept of government, whereby the state plays a key role in the protection and promotion of the economic and social well-being of its citizens, is based on the principles of equality of opportunity, equitable distribution of wealth, and public responsibility for those lacking the minimal provisions for a good life ${ }^{2}$ The

\footnotetext{
2 In performing this function, Bagwell and Staiger 1 have suggested that the critical values of any legal system include impartiality, neutrality, certainty, equality, openness, flexibility, and growth.
}

general values of governance may entail a dilemma surrounding economic and social factors. Public sector government efficiency at the aggregate as well as at the local level has become the subject of a rapidly growing literature. Deciding what are proper matters for the public sector as opposed to the private sector is probably the single most divisive issue in political philosophy, with socialists preferring greater state involvement, libertarians favouring minimal state involvement, and conservatives and liberals favouring state involvement in some aspects of society but not others.

Neoclassical economic theory affirms the superiority of free markets as the institutional backdrop most conducive to the generation of wealth. However, allies of big government rely on the modern theory that holds that government provision of public goods and services is warranted in cases of market failure or externalities in production. Markets often fail in the event of a natural monopoly (where average production costs decrease with increasing scale, and hence the most efficient industrial structure is a single producer) or in the case of public goods or services. Hall [5] stresses that although economic development is fundamental, it does not guarantee social protection.

Social democratic governments have introduced social security schemes but only a small minority have achieved effective social protection and made considerable advances in covering their populations, establishing what is often called a "welfare state". Virén [15] notes the general idea of the "welfare state", what refers to an ideal model of provision, where the state accepts responsibility for the provision of comprehensive and universal welfare for its citizens. The public provision includes basic education, health services, and housing (in some cases at low cost or without charge) featuring in many cases comprehensive health coverage and provision of state-subsidised public goods and services. Social protection is not delivered solely by the state, but by a combination of independent, voluntary and government services. Areas of debate include the financing of the pension system, health care and higher education, the transformation of the social insurance system, and the role of the state. Since the early 1990s the Scandinavian "welfare states" have been going through a long period of decline. In the early $1990 \mathrm{~s}$ their "welfare states" virtually collapsed.

The efficient Irish mode 3 combines the "welfare state" of continental Europe with the Anglo-Saxon liberal economy in a balanced fashion. Ireland has proved that a substantial lowering of the taxation level can become the impetus for launching even the most sluggish economy into top gear. Unprecedented growth led to an increase in fiscal revenue and social expenditure. This was sufficient to improve the productivity of the government.

Before implementing privatisation in the public sector the different standpoints of public debate should be taken into account.

\footnotetext{
3 A drastic reduction of the Irish tax rate, from 53\% in 1986 to its current $35 \%$, has led to a continuous boom of wealth creation at an average rate of $5.6 \%$ during the past two decades, while the number of jobs has grown by over $50 \%$ [20].
} 
Lack of finances and managerial skills call for a new approach to government efficiency in the public sector. It is especially important to clarify the negative impacts of privatisation, so as to be able to manage them. Section 2 examines the main outcomes and impacts of privatising public services.

\section{The impacts of privatisation on public services}

According to the World Bank's Independent Evaluation Group's calculation the public sector is the largest spender and employer in virtually every developing country, and it sets the policy environment for the rest of the economy. Public services play a key role in the life of every society; they bring long term benefits and influence all sub-sectors of a society. They cannot, therefore, function on a purely market basis, following a short term profit-focused logic. The quality of the public sector - accountability, effectiveness and transparency in service delivery - is thought by international organisations, such as the World Bank, [19] to contribute to overall development ${ }^{4}$ Improving the efficiency of government counterparts is also essential for the effectiveness of the public administration and to support development.

\subsection{Institutional factors of privatisation}

There is very strong pressure from international financial institutions and multinational enterprises to treat more and more services as part of government procurement and to subject them to competition and tendering. Giant corporations and international institutions are putting increasing pressure on governments to liberalise and privatise public services. The General Agreement on Trade in Services (GATS) is a commitment undertaken by the World Trade Organisation (WTO) members, to provide an international framework for the marketisation of services, including basic public services.

Public sector reform has assumed special urgency as CentralEastern European countries have faced recessions, alongside mounting demands for more and better public services. Accompanying these pressures, and the global credit crisis, have been demands for better government efficiency and more public accountability and control. In the past two decades, new forms of public sector management and privatisation have changed the way the public sector operates, but have also created a need for new ways of making governments accountable for what they do. With an increasingly devolved public sector, ensuring conformity with government policy objectives, control of expenditure and monitoring of actual agency performance have become increasingly complex. With many economies still in recession, afflicted by high and rising unemployment, it is difficult to finance the increased demand for public services delivered with a high level of quality. Nevertheless, there are also heartening

\footnotetext{
${ }^{4}$ Strengthening local planning, finance and service provision has been at the core of World Bank support through municipal development projects (World Bank, [19]).
}

signs that the civil society is more aware of the dire implications of what happens and has happened to their public assets.

The introduction of privatisation in the early 1990s established a mode of public service delivery that redefined the roles of the public and private sectors. In recent years, governments world-wide have sought to increase the involvement of the private sector in the delivery of public services. The longstanding view had been that efficient pricing and effective supply practices could be arranged by the government ownership or through regulating the private provider. Recently, two related concepts have been heavily promoted by neo-liberal governments: public-private partnerships (PPPs) and private finance initiatives.

Veress [13] has summarised the main reasons for and factors in privatisation as follows:

- to improve efficiency in public service delivery projects;

- the role of competition in bringing private finance to public service delivery;

- regulatory issues: fiscal rules and expenditure limits;

- the need for transparency and risk sharing;

- adequate institutional capacity;

- the public sector comparator;

- the importance of political support.

The marketisation mechanism involves deregulation, liberalisation and privatisation, a process which involves a government switching its focus from being an owner to being a regulator or a purchaser. The privatisation of public services entails the partial or complete sale of a government-owned business to the private sector. Some policies in this area concern governments buying services and so are a part of outsourcing, although much government procurement involves goods and equipment that they buy. These processes often start with the contracting out of services, described as the privatisation of services, moving later towards the actual sale and privatisation of facilities. There are differences in how these processes develop, which are perhaps most strongly influenced by the type of service in question and by the nature of the activity. In health care, social care, education and employment services the majority of countries have experienced some level of privatisation of services.

The societal necessity for these sectors to continue to provide public goods regardless of the presence of an applicable economic paradigm cautions policy makers against the unqualified adoption of market processes. Political and academic discussion has primarily focused on economic development and accessibility to different groups of citizens. Little attention has been paid, so far, to the impacts on local communities and governments. 


\subsection{Economic factors of privatisation}

Because services are mostly not storable, their exchange frequently requires the proximity of the supplier and consumer providers must move to the location of the buyer/consumer of a service, or vice versa. The significance of the proximity constraint for service transactions to be feasible means that trade will often involve a mixture of cross-border transactions and local presence of suppliers. The latter may be foreign or domestic - in general, service provision will often have an element of collaboration in production, as complementary inputs - including other services - are needed to allow the effective trade of a service to occur. This additional activity is partly outsourced to external service providers. Producer services therefore are not just differentiated inputs but play an important and distinct role in coordinating the production processes needed to generate differentiated goods and to achieve economies of scale. The associated organisational innovations and expansion of logistics (network) services yields productivity gains that in turn should affect economy-wide growth performance by enhancing the efficiency of production in all sectors 5

The private sector is often harnessed explicitly to avoid public debt -what is supposed to happen is that the annual fees for the service will be less than what the state would pay if it took out a loan to build the facility and ran it itself. The problem is that virtually all such schemes have both been more costly to build than anticipated and have resulted in greater cuts to those parts of the service remaining in public hands. One of the main aims of public management reform is to introduce private sector management practices, competition and private sector providers into the public sector. The idea of privatisation is supposed to be that the public sector, because of financial constraints and supposed gains in efficiency can access private sector money and management expertise without having to increase the public debt. Private firms are often more efficient than public sector organisations, and the processes of competition could bring efficiency gains in the delivery of public services. Under traditional public procurement, private sector firms competed in how to deliver detailed project specifications at the lowest possible cost.

The liberalisation of trade in services might generate new export opportunities by helping to attract foreign direct investments (FDI). Improving access to world class services, liberalisation should lead to a vigorous trade in services, with access to new markets, bringing better choice, higher quality, or cheaper services to consumers. Developing the local infrastructure (public transport, postal services, electricity, natural gas and water utilities, telecom/IT services) is one of the main goals of public sector reform initiatives.

\footnotetext{
5 Trade in services is still heavily dominated by developed countries: in 2005 they accounted for $81 \%$ of world service exports, versus $68 \%$ of goods exports. Growth between 1995-2005 has been very sharp: on average (in value) by $22 \%$ per year for computer and information services, $13 \%$ for financial services, $9 \%$ for insurance services, royalties and licence fees and $8 \%$ for cultural services (Eisenbach-Hoekman, $[4]$ ).
}

Some facilities are characterised by high external benefits or costs, and those who benefit may not pay for these while those who suffer the costs may not be compensated. Economic development has clearly beneficial effects on social welfare: the last 30-40 years have seen spectacular improvements in longevity, infant survival, access to basic amenities like water supplies and fuel, and the provision of services like health care and education. At the same time, this development has its casualties.

The structural adjustment favoured by international organisations, moving developing countries towards a formal market economy, has been criticised for pushing developing countries into a situation where their poor will be unprotected, which can lead to social polarisation, causing social crises for communities and local governments. However, Veress [14] claims that government policy intervention - such as taxation, subsidies, price and wage controls and regulations - may also lead to inefficient allocation of resources. Thus, there is often a choice between imperfect outcomes even when there is governmental intervention.

The impacts of privatisation, according to recent international surveys, include substantial job cuts, a significant reduction in pay, a deterioration in working conditions, and greater flexibility in working-time and employee relations ${ }^{6}$ Detailed statistics (Hall, [5]) in the UK (-41\% in the energy industry) and Germany $(-52.7 \%$ at railways) show that employment was cut by as much as $50 \%$ in the first 10 years of restructuring; in Sweden, employment was reduced by up to $30 \%$. Hall [5] notes that job cuts in private sector were even more dramatic, while the national employment rate remained stable in non-privatised sectors. Wages are reduced through changes in seniority-based raises as well as more general reforms of wage categories. In some cases, new employees are paid less than the existing workforce.

The main reasons for downsizing while making record profits might be that private companies often face a conflict between profitability and service levels, and may over-react to short term problems. A state-owned company might take a longer-term view, and thus be less likely to cut back on maintenance or staff costs, training etc, to stem short term losses. Internal restructuring often forces employees to leave a company due to a lack of mobility or problems in coping with rising insecurity and stress levels.

The market failures of privatisation may take many forms, but the usual one cited is that private provision results in highlypriced and under-provided public services. The individuals' pursuit of pure self-interest may lead to inefficient allocation of resources and could cause negative externalities. The supposed financial benefits of privatisation are often enjoyed by the private companies, and even if there are efficiency gains, the improvements which arise may not benefit workers or consumers.

\footnotetext{
${ }^{6}$ Stuckler, [17] documents a robust correlation between the extent of this and the adult male mortality rate using country-level data for about 24 economies of Eastern Europe and the former Soviet Union. A storm of controversy among defenders and attackers of "shock therapy" policies has ensued.
} 


\subsection{Market failure versus government failure}

A number of international examples demonstrate that public services cannot be operated on a purely market basis without causing severe social and environmental problems. It is acknowledged by many studies that there are winners and losers with privatisation. The number of losers - which may add up to the size and severity of poverty - can be unexpectedly large if the method and process of privatisation are seriously flawed. This can happen, for example, when there is a lack of transparency, leading to state-owned assets being appropriated for minuscule sums of money by those with political connections; or an absence of regulatory institutions leading to the transfer of monopolies from the public to private sector; or when the privatisation process is improperly designed and inadequately controlled. If a government-owned company providing an essential service (such as the water supply) to all the citizens is privatised, the different priorities of its new owners could lead to the abandoning of the social obligation to those who are less able to pay, or to regions where providing this service is unprofitable. A private company will serve the needs of those who are most willing and able to pay (maximizing profit goals), as opposed to the needs of the majority 7

Solving the negative impacts which communities face and the pursuit of the common good are not the principal tasks of the private economy, but the tasks of government. In the view of many social democrats market failures are a very common problem of any unregulated market system and thus they argue for state intervention in the economy in order to ensure both efficiency and social justice. Communities often prefer a governmental solution even when a market solution is possible. Both the democratic accountability of these regulations and the expertise of economists play an important role here in shaping the kind and degree of intervention.

Neo-liberals often focus on market-oriented solutions to market failures: for example, they propose going beyond the common idea of having the government charge a fee for the right to pollute (internalizing the external cost, creating a disincentive to pollute) to allow polluters to sell the pollution permits.

The Public Choice school argue that a failure of the market does not necessarily imply that it is the government that should attempt to solve market failures. Kaufman-Kaari-Mastruzzi [7] stress that the costs of government failure might be worse than those of the market failure it attempts to fix.

Weimer-Vining [16] argue that government failure (or nonmarket failure) occurs when a government intervention causes a more inefficient allocation of goods and resources than would occur without that intervention. This failure of government is seen as the result of the inherent problems of democracy and other forms of government as perceived by this school and also

\footnotetext{
7 The privatisation process of water system and the adoption of the total costprinciple had its part in the outbreak of the epidemic in South Africa, where the drastic increase of the water fees, has enabled to secure basic public service provision (Tradeagenda, [17|).
}

of the power of special interests both in the private sector and in the government bureaucracy.

Privatisation is likely to involve considerable risks and associated costs for the government and the community, where the conditions and impacts of privatisation are not manageable. Section 3 gives a framework to the background of the GATS negotiations, explaining the different standpoints of trading powers, developed and developing countries, as well as local governments.

\section{The General Agreement on Trade in Services and public services policies in the European Union}

The purpose of the General Agreement on Trade in Services (GATS) is to affect government policy on services to liberalise service provision, which will result in a reduction of government involvement in the service sector 8 In some cases this could mean the privatisation of public utilities, in others it would mean the further deregulation of an already privatised sector. GATS rules apply to 160 different service sectors - from education provision to rubbish collection, tourism services to transport policy, health delivery to the setting up of retail stores. Rules define four types of trade in services, depending on who or what (the service, the consumer or the provider) crosses the border ${ }^{9}$ This definition by the GATS of the four modes of trade in services has led to real strides in the understanding of globalisation in the service sector.

There is no agreed definition of services supplied in the exercise of governmental authority. The scope of the GATS depends on an understanding of the notions "supplied on a commercial basis" and "supplied in competition with one or more services suppliers." Such a service must meet two cumulative conditions: It must be supplied neither on a commercial basis nor in competition with one or more service suppliers. If a service is provided on a non-commercial basis but in competition with other suppliers or on a commercial basis but without competition, it is not a service supplied in the exercise of governmental authority. ${ }^{10}$

If a broad definition of commercial basis and in competition is adopted, the notion of governmental authority is narrow and almost all services would be covered by GATS. WTO members participating in these discussions felt that basic welfare and equity considerations had led to a very substantial degree of government involvement, both as a direct provider of such services and as a regulator in the health and social services sector. Governments must open up services markets to foreign companies, by signing them up to the GATS agreement and steadily remov-

\footnotetext{
${ }^{8}$ From the document MTN.GNS/W/124, available on the World Trade Organization Website.

9 The definition of service provision in the GATS draws heavily on the work of Bhagwati, [2].

10 The scope of the GATS is determined by Article I:3 of the Agreement: „Services“ includes any service in any sector except services supplied in the exercise of governmental authority. From the document MTN.GNS/W/124, available on the World Trade Organization Website
} 
ing barriers to trade. Veress [13] stresses that governments must be aware that corporate service providers, anxious for new markets, will use all their legal might to persuade the WTO to rule in favour of liberalisation.

\subsection{Public Services Policies in the European Union}

The European Union is in theory a common market with a common external trade policy. A common external tariff has long been in place for the EU. However, it remains an open question to what extent member states have a common structure of protection for the services sector. In practice this is very difficult to determine because the EU does not have common external services policies, with members retaining national competence in a number of sectors. The European Commission has already submitted initial negotiating proposals defining sectoral market access objectives.

As developed countries are losing shares of manufacturing markets to the emerging countries, incorporating trade in services into the scope of multilateral liberalisation may give them cause to hope they can conquer rapidly growing emerging markets. There are two rationales in the literature for the existence of trade agreements (Veress, [14]): The market access explanation is that agreements are a way of internalising the spillovers that are created by other countries' policies. This rationale emphasizes the terms of trade consequences of policies. The domestic political economy explanation puts the stress on the fact that trade agreements can be a vehicle for overcoming domestic resistance to desirable reforms and locking in such reforms. The associated cost reductions would result in an increase in overall total factor productivity for firms and the economy as a whole. Such producer services may of course be provided by foreign firms as well as domestic firms, with entry by foreign firms also being a channel for technology diffusion. Service corporations continue to pressure governments to accelerate negotiations and many corporate lobby groups have developed sophisticated sector-specific market access and policy reform objectives that they want to achieve through an expanded GATS.

The transition economies in the European Union have carried out numerous policy reforms in the services area. All had very small service sectors before 1990, reflecting the emphasis under central planning on industry and the bias against immaterial service sector activities. The political economy-based hypothesis in transition economies is more likely: trade agreements offer a mechanism for governments to signal their commitment to a particular policy path (Tumril, [6]).

The following is a list of criteria when taking a decision to invest in developing countries (Tanzi-Schuknecht, [9]):

- Potential market size, income per capita;

- existing competition, special treatment for local players;

- prospects for benefits in the short, medium and long terms;

- good governance (level of corruption, transparency of the legislation, etc.);
- the state of regulation (existing barriers, implementation of the regulations);

- FDI incentives (special zones, tax incentives, etc.);

- country risk assessment: political stability, sector specific binding commitments;

- social sensitivities must be taken into account.

The majority of developing country governments appear sceptical towards an agenda driven by foreign governments and transnational corporations. Transitional economies in particular, with a very limited track record on maintaining an open policy stance, can be expected to have had strong incentives to use membership of trade agreements for such credibility purposes. In addition, given very limited experience with market-based service sector policies, trade agreements may also have been valuable by establishing a template of (minimum) standards for trade and investment policy in the services area.

The GATS commitments are only an additional good reason for companies to invest. For the developing countries, it is an additional opportunity to seize in order to attract FDI. A common argument in the literature on regional integration and trade agreements more generally is that a rationale for participating in such agreements is to improve the terms of trade.

While there is substantial variance across transition economies on both actual policies and commitments, BagwellStaiger [1] argue that there is an inverse relationship between the depth of commitments and the quality of actual services policies as assessed by the private sector.

The current EU schedule affects in principle only the EU-12; for the other member states the national schedules are and remain in force until a new EU-27 schedule is negotiated. Latvia is the only one that went beyond the level of EU commitments, in particular in mode 4 for national treatment. Poland's limited use of the GATS as a commitment device is particularly striking. The Baltic States and some of the former Yugoslav republics revealing a strong interest in committing themselves in the GATS, Romania and Bulgaria have the lowest commitments. The Czech Republic, the Slovak Republic and Hungary appear to be highly committed to liberalisation. The average commitment index of these countries is the highest across the transition economies.

Eschenbach-Hoekman [4] suggest to transition countries greater incentive to use the GATS as a signalling and commitment device if they are small, geographically distant from large markets, and lack any prospect of joining the EU. In assessing the determinants of GATS commitments it is necessary to have an understanding of the actual policies applied by countries and the evolution in these policies. The objective is simply to focus on the question whether commitments help lock in a broader reform agenda and are a good signal for actual policies or policy direction. 


\subsection{The affect of GATS on local governments}

In the GATS negotiations only national government level representatives and decision makers participate, mostly even without consulting with the local levels, not taking into account their interests. The protection of the environment and the interests of the local farmers and local inhabitants, are in most cases adopted not by the national level government but by the local municipalities. This entirely contradicts the principles of subsidiarity and the European Charter of Local Self Government 11

Much concern has been raised by local governments about current negotiating proposals to develop new rules on domestic regulation, under the GATS. Sauvé-Stern [7] mention for example zoning, building permits and other local government regulations over the construction industry may be treated as barriers to trade. Environmental regulations in the public interest may be considered to be unnecessary barriers to trade. This means that the commitments of GATS could erobe the democratic freedom of local governments to create policies that best suit their communities at any given time. The civil society begun to vigorously attack GATS and launched the GATS free-zone campaign 12 A local authority will not be able to place, for example, a new restriction on retail developments for ecological or social reasons, if this specific restriction had not been listed by the government at the time of signing up the retail services sector to GATS.

The local council functions given by Sinclair [10] that could be affected by GATS are:

- Licensing the provision of services (taxis, food concessions);

- regulations on services (waste disposal, building codes, transport);

- planning permits (including discretionary powers to apply conditions or negotiate provision of social housing);

- any use of a discretionary power, giving preference to local employment or using procurement to promote the local economy.

As discussed at greater length in Section 2 and 3, both public and private forms of organisation have economic advantages and disadvantages. As a result of international pressures, local governments, in addition to their own financial problems, face intense competition in development.

\section{Recommendations to implement public management}

Local authorities construct, operate and maintain the economic, social and environmental infrastructure, oversee plan-

\footnotetext{
${ }^{11}$ Eschenbach-Hoekman $[4]$ explain that by the fact that the prospect of EU accession makes GATS less relevant as a commitment device for a subset of transition economies. One explanation is that the small size of the markets concerned generates weak external enforcement incentives.

12 In Austria more than 100, in France 218, in Italy 10, in the United Kingdom 12, in Canada 68, in New-Zealand another 3 and in Australia many dozen (such as Melbourne). Avaible at [17] "Lies, damn lies and what the GATS really says" avaible at http://www.tradeagenda.com
}

ning processes, establish local environmental policies and regulations, and assist in implementing national and sub-national environmental policies.

The decentralised decision making system, and a national economy based on local elements are more suitable to satisfy local needs. Local governments must be able to manage their public services in line with their complex objectives, coordinate the development process through planned, transparent and organised cooperation with the stakeholders (that is, all those affected by the local government's decisions and actions: such as the end-users of public services, clients, citizens, private sectorbusinesses, non-profit organisations, civil sector and the state).

In order to develop, settlements have to offer some form of competitive advantage. There is no widespread agreement on the factors and methods that can help local governments to move from under-performance to competence.

Competitiveness is a concept which comes from the business world, and from a profit orientated view effectiveness is related to high living standards, environmentally friendly production, managing negative externality and building international contacts.

In Table 1 the author summarises the key factors of competitive local governments.

One possible way of gaining an advantage is the creation of a unique local strategy for the settlement by using the principles of public management. Public management is based on the principle that governments and the public sector should use the management tools of the private sector to maximize efficiency. Public management means building up an implementing a longterm strategy aimed at sustainability and improving living standards and developing an entrepreneur-friendly environment. As the local level of governance is closest to the people, they play a vital role in educating, mobilizing and responding to the public to promote sustainable development. ${ }^{13}$ Public management holds that it is the task of the leadership to accomplish the successful management of local resources. We can define a public project as a change in net supplies in commodities from the public sector.

\subsection{The emergence of strategic planning}

While an increasing emphasis on privatisation has reduced the proactive role of the national government in the economy and society, generally speaking central states continue to exercise a dominant role. Because of the diversification of decisionmaking and a restructuring of intergovernmental relationships in which the relative strength of the different governmental levels has changed, national governments now interact with other levels of government in far more complex ways. The division of power between the municipal and the sub municipal level is

\footnotetext{
13 At the Rio Earth Summit in 1992, the United Nations agreed that the best starting point for the achievement of sustainable development is at the local level. In fact, two thirds of the 2500 action items of Agenda 21 relate to local councils (Unated Nations, $[11]$ ).
} 
Tab. 1. The key factors of competitive local governments

\begin{tabular}{lll}
\hline Strategic goals, targets & Key factors & Specific approaches. Methods \\
\hline Competitive foreign and local enterprises, & Integrated local strategic planning, & Supporting a local industry park (infrastructure, \\
High living standards, & Special situational factors to motivate FDI & tax rebates, subsidies, preferential credit facili- \\
Low social expenditures, & from foreign companies & ties for small enterprises), \\
Avoiding negative externalities & Development, & Maintaining local initiatives (preferring local \\
& Improvements, innovation & products, supporting local tourism), \\
& & Preferring local employment by local public \\
& & projects
\end{tabular}

Clear and calculable resources for develop- Territorially decentralised adequate funding ment

Substantial flow of finances
Economical provision of local services according to local demand; cost-effectiveness analysis,

Outsourcing,

Co-finance, PPPs

\begin{tabular}{lll}
\hline $\begin{array}{l}\text { Good governance - good image, trans- } \\
\text { parency }\end{array}$ & $\begin{array}{l}\text { Public participation, co-operation with stake- } \\
\text { holders, appropriate skills, }\end{array}$ & Performance management; \\
& low level of corruption, transparency & Human resource management; i.e. teamwork \\
& & Information management
\end{tabular}

Source: Self-developed

less relevant in cases where the local level is generally weak. In this sense it might be possible to speak of a "powerless local government" in which case the regional or national level has the leading role, with the local government having hardly any power at all, as compared to the higher administrative levels. This depends both on the grass-roots organisations' capacity to adapt successfully and to the ever changing institutional environments of which they form a part, and on the will of public administrations to continue co-operating with those civil society organisations.

The integrated strategic plan aims to underline development actions which link planning with implementation. The investment decision procedure, should involve the following steps and methods:

1 Formulation of implementation plans: data collection and setting of targets based on local needs and citizens' comments, identifying alternative strategies based on stakeholders needs;

2 Implementation of projects by identifying the consequences of each alternatives;

3 Evaluation of achievements by estimating the cost and revenues in each period of time (discounting);

4 Review of action by adding up the discounted costs and revenues and calculating the internal rate of return for each alternative so as to choose the most profitable and sustainable one.

Each local authority has had to draw up its own strategy. Local communities have to define their development priorities since these are the basis for father allocation of resources. The principle of sustainable development must form a central part of the local strategy regarding sustainable development as a community issue, involving all sections of society, including community groups and businesses.

\subsection{Adequate funding}

The developmental and environmental objectives of a local strategy will require a substantial flow of new and additional financial resources, in order to cover the incremental costs for the actions they have to undertake to deal with global environmental problems and to accelerate sustainable development. Local governments should look for and capture economies of scale and scope. One very effective way to reduce cost is to identify and capture economies of scale or scope through cooperative arrangements or outright consolidation with other public agencies or private companies. Private sector finances could help to manage the public service delivery, which is known as outsourcing.

A difficulty in defining and regulating PPPs in Hungary stems from restrictions on transferring core municipal property to the private sector. Since PPP payments are not yet regulated by national law at the municipal level, their inclusion in debt limits or in a separate category of obligation, which exists at the state level already, means municipalities face a significant policy risk if they engage in projects that meet PPP standards. Choosing a PPP arrangement only to avoid a particular accounting or statistical classification is a potentially dangerous practice that is to be avoided by providing transparent instructions to ensure value for money.

The typical problems of calculating the benefits of a project concern identifying and evaluating the direct and indirect effects of the project. Choosing the best project should be carried out on the basis of the net present value (NPV) of costs and ben- 
efits and the internal rate of return (IRR). Valuing the internal and external environment of public services and goods is particularly difficult, but STEEP and SWOT analyses could help to implement the best strategy. To measure the effects of public services on life, health and safety, it may be useful to adopt a cost-effectiveness analysis, which avoids attributing values to the benefits which are identified only in physical and qualitative terms. A problem with this method is that it identifies the value of human life with the value of earnings, which is immoral. A cost-effectiveness analysis considers the positive and negative externalities of the project, as well as incommensurable costs and benefits. If the valuation of public services produced by the project is not competitive, shadow prices should be used instead of market prices. Shadow prices represent the true marginal social benefit or cost.

Decision-makers should focus on measuring the costs and benefits of alternative ways to achieve the object of the project. Government agencies will then reject the least attractive option, in much the same way as a private investor would do.

If financial resources are calculable and clear, then the basic precondition for planning is provided. Local enterprises and development funds with pro-active development plans for the municipality can support sustainable development. The use of development resources should be combined with the continuous monitoring of resources and assets.

\subsection{Good governance - good image and performance}

For successful governance not only financial resources but appropriate skills are needed. There is no general model of motivating public employees because different societies face very different risks and problems, however some general recommendations can be given.

Analysing the internal environments of the organisation is necessary to identify the capabilities present. There must be the right number of staff, of the right kind for the implementation of public management. Downsizing and employment cuts could generally be managed in socially acceptable ways, such as by offering early retirement, redundancy payments above the legal requirement and training for new jobs. In a similar way, income reductions rarely stem from direct cuts in basic wages. Regarding the employees, the aim is to develop a sense of responsibility and quality among the managers and staff and to develop the ability to take on responsibility and create methods to motivate the staff. Increased job satisfaction and learning opportunities as well as the enforcement of team work and the development of a shared organisational culture are the aims of development in an organisation. Local decision-makers should communicate clearly and consistently with staff and contacts between departments play a vital role. The congruence of the interests of public sector workers and the citizens in the provision of quality public services is the key to success.

\section{Concluding remarks}

Public goods and services have become increasingly important as a vehicle to generate economic growth, reflecting the increasing specialization and exchange of services on markets, with an associated increase in variety and quality and a reduction in real costs. The basic functions of municipalities strongly influence the quality of life of their inhabitants.

Given the increasing importance of the service sector, services policies have become a prominent element of trade negotiations. Mechanisms like the General Agreement on Trade in Services (GATS) may affect the supply of public services. The benefits of membership of GATS may need to be qualified through more effective multilateral monitoring of implementation of commitments, even with the participation of local level representatives and decision makers. Decisions of strategic importance, such as joining GATS, should be made only after a thorough social debate, with a view to the ecological and social aspects of sustainability, taking into account the interests of future generations.

Local decision makers are more suited to managing innovative service supply networks capable of renewal and adoption to the changing local needs as they know the local conditions and can maintain good relations with the local community. They can better discover how to achieve the best results in ecologic and social terms out of an investment.

The need for public management is reinforced by the following considerations:

- Strategic management is necessary to attract sufficient interest from investors to achieve good economic performance;

- local governments may have to subject all measures affecting services to a necessity test, which would oblige them to take the measures which are the least restrictive of trade possible while fulfilling a public policy objective;

- local governments need to use a wide range of techniques to control costs and to maintain financial credibility with their communities through continuous communication;

- there is a need to measure performance and provide rewards or penalties as appropriate in order to ensure that staff at all levels are encouraged to either improve the quality or reduce the cost of service;

- decisions should be made in open processes, with transparency and public participation.

In conclusion, local governments should adopt public management more positively, dealing with the various aspects of the development process of their local economies in line with their key objectives. The key factors of competitive local governance should involve strengthening strategic planning, finance and service provision, by using the principles of effective and sustainable management of their resources. 
Under the extremely decentralised circumstances of Hungary with nearly 3200 local governments, successful public management requires consultation and consensus-building with the stakeholders and the gathering of all the information needed for formulating the best strategies.

Formal and informal organisations, as well as grass-roots movements, should be recognized as partners. The broadest public participation and the active involvement of nongovernmental organisations and other groups should also be encouraged. Representatives of associations of local authorities are encouraged to establish processes to increase the exchange of information, experience and mutual technical assistance among local authorities.

To avoid false starts in strategic planning, local administration has to strengthen services engaged in collecting information on the strategies of local authorities, in particular those that need international support. Periodic sectoral consultations involving both international partners and international support could be initiated. Players within the micro-regions should submit their own ideas to their local Rural Development Offices so that they may be involved in the planning process and contribute to the establishment of a complex strategy.

\section{References}

1 Bagwell K, Staiger R, The Economics of the World Trading System. Cambridge, MA: MIT, 2002, available at http://wWw.wto.org/english/ tratop_e/serv_e/s_propnewnegs_e.htm. Downloaded: 03.04.2008.

2 Bhagwati J N, Why are Services Cheaper in the Poor Countries?, Wealth and Poverty, Vol. 1, MIT Press, Cambridge. edited by Gene Grossman Essays in Development Economics Series, 1985, pp. 82-91.

3 Eschenbach F, Hoekman B, Services Policies in Transition Economies: On the EU and WTO as Commitment Mechanisms, World Bank and CEPR, World Bank Policy (2000), 10-27. Research Working Paper 3951.

4 Hall J, Private Opportunity, Public Benefit?, Fiscal Studies, Institute for Fiscal Studies, U.K., 1998, pp. 120-141.

5 Kaufmann D, Kaari A, Mastruzzi M, Governance Matters - Governance Indicators for 1996-2006, World Bank Policy Research Paper 4280 (2007), 3-8.

6 Sauvé P, Stern R M, New Directions in Services Trade Liberalization (2000), 487-508. ed. Washington, DC: Brookings Institution.

7 Tanzi V, Schuknecht L, The growth of government and the reform of the state in industrial countries, IMF Working Papers 95/130, available at http://www.imf.org/external/pubs/ft/fandd/1996/ 09/pdf/tanzi.pdf. Downloaded:04.05.2009.

8 Tumlir J, Trade Policy in Democratic Societies, American Enterprise Institute, Washington, DC, 1985.

9 Sinclair S, The GATS negotiations: "state of play", Canadian Centre for Trade and Investment (2001), no. 2, 1-5.

10 UNITED NATIONS, Division for Sustainable Development: Local Agenda 21, 2002, available at WwW.un.org/esa/sustdev/agenda21.htm. Downloaded: 02.07.2009.

11 VEDEGYLET: Liberalisation of public services and GATS agreement, Budapest, 2007, available at www.vedegylet.hu/conferences/ GATSstatement.pdf. Downloaded: 04.03.2009.

12 Veress J, Externalities of Globalisation, Periodica Polytechnica 10 (2002), no. 2, 215-226.

13 , End of the Economic Policy. The Case of Hungary, Periodica Polytechnica 12 (2004), no. 2, 122-137.
14 Virén M, Financing the Welfare State in the Global Economy, The Research Institute of the Finnish Economy Discussion Papers (2000), no. 732, 10-16.

15 Weimer D, Vining A, Policy Analysis and Concepts, 2004. Englewood Cliffs, 4. ed.

16 available at www.tradeagenda.com/files/commentaries/wta0023c. html. Downloaded: 05.07.2009.

17 available at wWw.voxeu.org/index.php\{\%\}3Fq\{\%\}3Dnode/3212+ Stuckler+et.+al.pdf. Downloaded: 04.03.2009.

18 WORLD BANK, available at wWw.worldbank.org/EXTMMNGT/ Resources/exec_summary.pdf. Downloaded:15.07.2009.

19 WORLD TRADE ORGANISATION: GATS -Fact and fiction, Geneva, 2001, available at www.wto.org/english/tratop_e/serv_e/s_ propnewnegs_e.html. Downloaded: 01.07.2009.

20 available at wWw.workforall.net/IRELAND_The_wealth_of_the_ nation.pdf. Downloaded: 15.07.2009. 